\title{
ANALISA SISTEM ADMINISTRASI YANG SEHAT DALAM PENERAPAN TSAR (TIMEREGISTERING SYSTEMATIK VEDIKE HOLD ARKIVERING AND RESERVEDELER) TERHADAP MANAJEMEN PERAWATAN DAN PERBAIKAN PERMESINAN
}

\author{
KAPAL
}

Ali Khamdilah ${ }^{1)}$

${ }^{1)}$ Program Studi Teknika Akademi Pelayaran Niaga Indonesia ali.khamdilah@akpelni.ac.id

\begin{abstract}
ABSTACTION
Achieving good ship operation requires a system that can serve, monitor, control work.

Ship management is how to manage, manage, regulate activities on board which covers all aspects of daily ship operations to achieve the destination of the shipping company. The implementation of integrated management such as TSAR (Timeregistering Systematisk Vedli Kehold Arkivering and Reservedeler) is a management system used to get the basics of specific maintenance information, pictures of instructions, use of materials so that it will facilitate the work on target.
\end{abstract}

Keywords: administration, TSAR, Maintenance and repair management

\section{ABSRTAK}

Tercapainya Pengoperasian kapal yang baik dibutuhkan suatu sistem yang dapat melayani,memonitoring,mengontrol pekerjaan.Ship management atau manajemen kapal adalah bagaimana mengelola,mengurus,mengatur kegiatan diatas kapal yang mencakup seluruh aspek kegiatan pengoperasian kapal sehari hari untuk mencapai tujuan perusahaan pelayaran.Penerapan manajemen terpadu seperti TSAR (Timeregistering Systematisk Vedli kehold Arkivering and Reservedeler) merupakan suatu sistem manejemen yang digunakan untuk mendapatkan dasar-dasar informasi 
perawatan secara spesifik, gambar-gambar instruksi, penggunaan material sehingga akan mempermudah dalam perkerjaan secara tepat sasaran.

Kata kunci :administrasi,TSAR, Manajemen perawatan dan perbaikan

\section{A. Pendahuluan}

Didalam suatu bisnis dalam dunia pelayaran yang berhubungan dengan pengoperasian kapal,dibutuhkan suatau sistem yang dapat melayani pekerjaan diatas kapal sebagai tujuan pada kelancaran pengoperasian kapal secara baik.

Tujuan dalam suatu usaha secara umum adalah mendapatkan keuntungan dengan bisa menekan biaya perawatan dan perbaikan seefisien mungkin.

Ketertiban dalam sistem administrasi diperlukan sebagai analisa pemasukan dan pengeluaran biaya ataupun tentang hal hal yang berhubungan dengan prioritas pekerjaan perawatan ataupun perbaikan pesawat permesinan dikapal.

Sesuai pendapat para ahli bahwa manajemen adalah pengelolaan suatu organisasi /kegiatan untuk mencapai tujuan yang telah ditetapkan ,melalui kegiatan orang lain.

Ada ship management(manajemen kapal ) dan Shipping management (manajemen pelayaran atau manajemen perkapalan) yang mempunyai pengertian berbeda ,tetapi pasti kedua manajemen tersebut mempunyai hubungan yang sangat erat.

Ship management atau manajemen kapal adalah bagaimana mengelola,mengurus,mengatur kegiatan diatas kapal yang mencakup seluruh aspek kegiatan pengoperasian kapal sehari hari untuk mencapai tujuan perusahaan pelayaran.(sesuai buku ship management oleh Harry Gilbert dari IMO).

Tujuan pengoperasian kapal antara lain agar pengoperasian kapal lancar,tertib, dan efisien,keselamatan pelayaran 
terjamin,muatan sampai ditujuan dengan tepat waktu,aman dan terhindar dari claim serta tujuan perusahaan tercapai.

Sesuai prinsip manajemen tentu hanya dapat dicapai atas bantuan dan kerjasama dari seluruh yang terlibat dalam kegiatan tersebut.

Sedangkan shipping management adalah bagaimana mengelola seluruh kegiatan perusahaan pelayaran (bidang arnada, komersil/operasi dan keuangan/administrasi), tentu saja termasuk manajemen manajemen kapal-kapalnya,untuk mencapai tujuan perusahaan pelayaran tersebut

\section{B. Landasan teori}

\section{a. Pengertian administrasi dan manajemen}

1 Administrasi adalah kegiatan atau proses yang berkenaan dengan upaya /jalan untuk mencapai tujuan .

Menurut Dr.Sondang P.Siagian MBA,Administrasi adalah keseluruhan proses kerjasama antara dua orang atau lebih yang didasarkan atas rasionalitas tertentu untuk memcapai tujuan yang telah ditetapkan.

2 Manajemen adalah pengarahan menggerakkan sekelompok orang dan fasilitas dalam usaha untuk mencapai tujuan tertentu

Menurut George R.Terry, manajemen adalah pencapaian tujuan yang telah ditetapkan sebelumnya melalui usaha orang orang lain

JadiAdministrasi adalah penyelenggarannya danManajemen adalah orang orang yang menyelenggarakan kerja

b. Hal - hal yang diperhatikan pada administrasi agar sesuai harapan kerja

1 Sumber daya manusia

Menurut Faustino Cardoso Gomes (2003:1), sumberdaya manusia merupakan satu sumberdaya yang terdapat dalam organisasi, meliputi semua orang yang melakukan aktivitas. 
2 Tertib Administrasi

Dalam Kamus Bahasa Indonesia (1985) , definisi tertib adalah aturan, peraturan yang baik. Jika peraturan yang dibuat dapat ditaati semua instansi perusahaan termasuk karyaannya dengan baik pula maka, semua pekerjaan yang dijalankan akan berjalan lancar..Dan apabila tertib atau aturan tidak ditaati (dilanggar) maka, konsekuensinya adalah buruknya administrasi, cara yang bisa ditempuh dengan menetapkan sangsi yang berat bagi yang melanggar tertib administrasi adalah tertata dan terlaksana dengan rapi, teratur, menurut aturan terhadap semua kegiatan tata usaha agar tidak terjadi tumpang tindih, sehingga dapat dipertanggungjawabkan serta penyelenggaraanya diwujudkan melalui fungsi-fungsi administrasi

Ukuran atau indikator tertib administrasi meliputi :

- Penyeleksian data atau pemberkasan

Menurut Andrew E. Sikula dalam Anwar Prabumangkunegara (2002:35) penyeleksian adalah pemilihan. Menyelidiki merupakan suatu pengumpulan dari suatu pilihan. Proses seleksi melibatkan pilihan dari berbagai objek dengan mengutamakan beberapa objek saja yang dipilih.

Strategi Campbell, Dunnette, Lawler, Weick (1970) didasarkan pada penggunaan dari metode mekanikal/klinikal dalam mengumpulkan dan mengolah data. Pengumpulan data secara mekanikal ialah jika data dikumpulkan berdasarkan pedoman-pedoman, peraturanperaturan, dan prosedur yang telah ditetapkan semula.

- Pengelompokkan data

Sebuah artikel yang dibuat oleh I Made Anom Ariawan, dkk menjelaskan bahwa 
pengelompokkan data adalah sekumpulan data yang besar dengan cara membagi data tersebut kedalam beberapa gerombolan /kelompok. (http://ejournal/matemetika/vol2/No4/nop2013/17 .22)

Tujuan pengelompokan data adalah untuk mempermudah proses analisis dan interpretasi dari data besar dengan membagi data tersebut menjadi beberapa kelompok. Terdapat beberapa teknik dalam pengelompokkan suatu data, pengelompokkan data yang dimaksudkan adalah pengelompokkan data yang didasarkan pada objek dari data tersebut. Salah satu analisis yang sering digunakan untuk pengelompokkan ini adalah analisis gerombol (cluster).

- $\quad$ Pengelolaan data

Menurut Hamiseno (1978:1), pengelolaan adalah subtantif dari mengelola. Mengelola berarti suatu tindakan yang dimulai dari penyusunan data, merencana, mengorganisasikan, melaksanakan, sampai pengawasan dan penilaian. Pengelolaan juga menghasilkan sesuatu dan sesuatu itu dapat menjadi sumber penyempurnaan dan peningkatan pengeloaan selanjutnya.

Untuk mencapai efektivitas dan efisiensi yang tinggi, segala kegiatan dan tindakan harus dilaksanakan dengan pertimbangan dan perhitungan yang rasional.

Guna menjamin dan menciptakan rasionalitas yang tinggi, perlu langkah-langkah kegiatan atau disebut dengan fungsi pokok administrasi.

Adapun fungsi-fungsi pokok administrasi menurut pandangan para ahli seperti 
1 Perencanaan (Planning)

Menurut Siagian (2003:88) dalam bukunya yang berjudul Filsafat Administrasi, Planning dapat didefinisikan sebagai keseluruhan proses pemikiran dan penentuan secara matang tentang hal-hal yang akan dikerjakan dimasa yang akan datang dalam rangka pencapaian tujuan yang telah ditentukan

2 Pengorganisasian (Organizing)

Adalah menentukan tugas dari pada personil yang akan melekukan kegiatan

3 Actuating

sebuah tindakan yang dilakukan untuk mengusahakan supaya semua anggota kelompok berusaha untuk mencapai sasaran yang sesuai dengan perencanaan manajerial serta usaha-usaha organisasi.

4 Pengawasan

Hal ini sangat penting untuk menjaga terlaksananya pekerjaan dengan baik dan selesai tepat waktu

\section{c. Pengertian TSAR (Timeregistering Systematisk Vedli kehold Arkivering and Reservedeler)}

Merupakan singkatan dari timeregistering systematik vedike hold arkivering and reservedeler yang berarti catatan kerja sistimatik perawataan kearsipan dan sistem suku cadamg ,sistim ini telah di perkenalkan pada industri perkapalan sejak tahun 1971,dan sejak itu telah di pergunakan secara meluas dalam industri perkapalan dan lepas pantai.

System TSAR Telah dikembangkan oleh THE SHIP RESEARCH INSTITUTE OF NORWAY (Lembaga penelitian perkapalan Norway) bekrja sama dengan indusry perkapalan Dengan system administrasi yang baik maka perencanaan pemeliharaan suatu instalasi pesawat - pesawat di kapal akan meningkatkan tingkat keselamatan.

Salah satu tujuan penggunaan kode klasifikasi teknik sistim perawatan TSAR. 
Adalah untuk mendapatkan dasar-dasar informasi perawatan secara spesifik,gambar-gambar instruksi,penggunaan material sehingga akan mempermudah dalam perkerjaan secara tepat sasaran.

\section{d. Manajemen perawatan dan perbaikan mesin kapal}

Dalam SOLAS 1974/1978 Chapter II Part C, D, E, dengan jelas menegaskan bahwa semua kapal dari Negara IMO (International Maritime Organization)harus melaksanakan "Perawatan dan Perbaikan Mesin Kapal".

Tujuan umum Sistem Perawatan dan Perbaikan Mesin Kapal seperti : memperoleh pengoperasian kapal yang teratur, serta meningkatkan penjagaan keselamatan awak kapal, muatan dan peralatannya,memperhatikan jenis-jenis pekerjaan yang paling mahal / penting yang menyangkut waktu operasi, sehingga sistem perawatan dapat dilaksanakan secara teliti dan dikembangkan dalam rangka penghematan / pengurangan biaya perawatan dan perbaikan, menjamin kesinambungan pekerjaan perawatan sehingga Team Work's Engine Department dapat mengetahui permesinan yang sudah dirawat dan yang belum mendapatkan perawatan. mendapatkan informasi umpan-balik yang akurat bagi kantor pusat dalam meningkatkan pelayanan, perancangan kapal dan sebagainya, sehingga fungsi kontrol manajemen dapat berjalan.

Perawatan dan perbaikan dengan mengacu kepada pemantauan kondisi secara berkelanjutan, hal ini memang memerlukan kondisi suku cadang yang cukup, sehingga semua perawatan dan perbaikan dapat dilaksanakan tanpa menunggu pengadaan material yang baru.

Perawatan dan perbaikan sesuai Manual Instruction Book, yaitu pendekatan ukuran material yang dipakai kepada "Standard Measurement" yang diizinkan oleh "Maker".

Perawatan dan Perbaikan Mesin terbagi menjadi dua bagian,yaitu: 
- PMS (Planned Maintenance System ) Sistem Perawatan Terencana

adalah sistim perawatan yang dilakukan terhadap pesawatpesawat permesinan dan peralatan lainnya di kapal secara terencana dan bersinambungan, menurut petunjuk Makernya masing-masing untuk menghindari terjadinya kerusakan (breakdown) yang dapat menghambat kelancaran beroperasinya kapal.

- CMS (Continuos Machinery Survey)

Biro Klasifikasi mengeluarkan daftar CMS dimana jadwal overhaul komponen pesawat permesinan dan perlengkapan kapal yang termasuk dalam daftar tersebut, harus dioverhaul untuk perawatan dan diperiksa oleh Surveyor Klass (Classification Surveyor).

Tiap tahun minimum 1/5 dari daftar CMS dioverhaul untuk diperiksa sehingga pada tahun kelima, seluruh komponen pesawat permesinan dan peralatan kapal dari daftar CMS telah selesai dilakukan

Apabila pada saat diadakan overhaul tidak memungkinkan kehadiran Surveyor dari Biro Kiasifikasi kapal, maka Chief engginer dapat melakukannya.

Survei oleh Chief engginer merupakan Confirmatory Survey yang nantinya akan disyahkan oleh Surveyor dari Biro Kiasifikasi kapal, jika laporan tertulis lengkap dengan fotofotonya untuk bukti telah dipelajari dan memenuhi syarat

\section{Pembahasan}

\section{Ketidaksiapan administrasi dalam kegiatan perawatan dan perbaikan}

Saat melakukan kegiatan perbaikan pada pesawat dikamar mesin perlu adanya persiapan - persiapan yang baik,mulai dari persiapan manusianya ,pesawat yang akan diperbaiki,peralatan yang dibutuhkan sampai dengan suku cadang (spare part) yang akan digunakan,sehingga pekerjaan tersebut akan berjalan sesuai dengan prediksi waktu yang telah ditentukan.Seiring waktu, 
banyak hal- hal yang menghambat dalam proses kegiatan tersebut.

Kejadian tersebut muncul dikarenakan dalam prosesnya tidak mengikuti prosedur yang telah ditepatkan oleh perusahaan yang tertuang dalam SOP (Standart Operational prosedure).

Peran seorang pimpinan diperlukan untuk mengatur pekerjaan tersebut sesuai dengan harapan.

Sering dijumpai tidak tertibnya administrasi pada serangkaian kegiatan perbaikan pada pesawat tersebut, seperti:

- Spare part yang tidak sesuai dengan kondisinya

- Laporan jam kerja pesawat yang tidak muncul pada pelaporan kerja

- Tidak tersimpannya data /asrip dengan baik

\section{Pemecahan masalah}

Upaya mengatasi ketidaksiapan administrasi dalam kegiatan perawatan dan perbaikan

Agar pekerjaaan perbaikan pesawat tersebut berjalan dengan baik diperlukan suatu sistim terpadu,dimana agar bagian bagian dalam menunjang pekerjaan tersebut bisa berjalan dengan baik

Kemampuan dan keahlian manajemen dalam hal ini sangat diperlukan dengan harapan, agar dalam pengolahan data pekerjaan dikamar mesin kapal dapat berjalan dengan baik,seperti

- Pengecekan jenis suku cadang dari seatiap mesin ataupun alat yang diperlukan,termasuk merk,type mesin ,nomor seri,nomor suku cadang

- Pengecekan jumlah suku cadang dari setiap suku cadang dan jika dianggap kurang

- Pengajuan permintaan kekantor pusat

Guna mendapatkan tertib administrasi yang baik pada sistem tersebut dibutuhkan aturan aturan yang mengikat yang digunakan sebagai acuhan dalam pekerjaan tersebut.Hal tersebut sangat dibutuhkan sebagai bagian 
peranan utama dalam pekerjaan.Serta perlunya adanya sangsi ataupun hukuman yang berdampak.

Peran aktif yang dilakukan seorang pimpinan harus dilakukan sebagai bentuk pengontrolan terhadap hasil kerja

\section{E. Kesimpulan}

1 Suatu pekerjaan akan berjalan dengan baik apabila dalam pelaksanaan tersebut diterapkan suatu sistem yang terpadu sebagai alat pengontrol,seperti

- dalam memulai pekerjaan

- proses pekerjaan

- hasil dari pekerjaan tersebut

2 Penerapan TSAR pada manejemen perbaikan dan perawatan sangat efektif jika didukung oleh pembentukan sumber daya manusia yang baik.sehingga berpengaruh dalam proses pekerjaan.

\section{Daftar Pustaka}

https://www.gurupendidikan.co.id/pengertian-administrasi/

Harry Gilbert, Ship management, International Maritime Organization

http://ejournal/matemetika/vol2/No4/nop2013/17.22

SOLAS 1974/1978 Chapter II Part C, D, E

https://citraperdanas.wordpress.com/engine/perawatan-

permesinan/perawatan-dan-perbaikan-mesin-kapal/

Bessie .J.A,Perawatan dan Perbaikan Mesin,Jakarta 2013

Bessie.J.A,Manajemen Perawatan Mesin dan Keselamatan Kerja,Jakarta 2013 